\title{
Localisation of fibronectin mRNA in the rheumatoid synovium by in situ hybridisation
}

\author{
H A Waller, M G Butler, J G B McClean, G S E Dowd, D L Scott
}

\begin{abstract}
The distribution of fibronectin, an extracellular matrix glycoprotein which plays a part in fibrosis and tissue repair, has previously been described using immunohistochemical methods. These do not differentiate between locally synthesised and plasma derived fibronectin. In this work the distribution of cells actively synthesising fibronectin was assessed by in situ hybridisation using a radiolabelled antisense RNA probe in synovial biopsy samples from patients with rheumatoid arthritis, osteoarthritis, ankylosing spondylitis, and control subjects without inflammatory disease. Large amounts of fibronectin mRNA were found specifically in synovial lining cells, providing evidence for the local production of fibronectin in the synovium. Levels of fibronectin mRNA were variable between patients. These differences were not related to the diagnosis or to the subintimal inflammatory cell infiltrate; where there was synovial lining cell hyperplasia there was a concomitant increase in the number of cells containing fibronectin mRNA, which was consistent with increased levels of immunoreactive fibronectin at this site. Increased levels of fibronectin in synovial fluid in patients with rheumatoid arthritis may be due to an increased number of lining cells secreting the protein, rather than upregulation of the gene by these cells.
\end{abstract}

Department of

Rheumatology,

St Bartholomew's

Hospital Medical

College,

Charterhouse Square,

London EC1M 6BQ,

United Kingdom

H A Waller

D L Scott

Department of

Immunology,

St Bartholomew's

Hospital Medical

College,

Charterhouse Square,

London EC1M 6BQ.

United Kingdom

H A Waller

M G Butler

Department of Orthopaedics,

St Bartholomew's

Hospital Medical

College,

Charterhouse Square,

London EC1M 6BQ,

United Kingdom

J G B McClean

G S E Dowd

Correspondence to:

Dr Waller.

Accepted for publication

19 November 1991 cross reactivity. Structural variants arise from a single gene via a complex pattern of posttranscriptional and post-translational events. Through the ability to bind cells and components important parts in normal tissue development and turnover, wound repair, and inflammatory processes characterised by tissue remodelling. ${ }^{1-4}$

The distribution of fibronectin in the rheumatoid synovium has been extensively electron microscope levels. ${ }^{5-10}$ Fibronectin is a major extracellular matrix component of synovial tissue and, similar to its distribution in other tissues, ${ }^{4}$ is found to codistribute with fibrin, immature collagen, and reticulin fibres. It is also located in the perivascular connective tissue and basement membranes of capillaries and small blood vessels. Extracellular fibronectin is prominent in the synovial lining cell layer and is increased at sites of synovial cell hyperplasia, with intracellular fibronectin often evident. $^{56910}$ There is a marked increase in extracellular fibronectin particularly associated with the proliferative pannus, though there is no evidence that changes in the distribution of fibronectin are disease specific. ${ }^{11} 12$ The level of synovial fluid fibronectin in rheumatoid arthritis is increased compared with plasma levels 57813 and extracellular fibronectin is secreted by synovial cells in culture. ${ }^{14}$ These observations strongly suggest that fibronectin is synthesised within the synovium, and that the synovial lining cells provide a source of synovial fluid fibronectin, though plasma fibronectin may also contribute a considerable amount.

To ascertain the sites of fibronectin synthesis within the synovium we used in situ hybridisation. ${ }^{15}$ Synovial biopsy samples from patients with rheumatoid arthritis, ankylosing spondylitis, osteoarthritis, and control subjects without inflammatory disease have been investigated to evaluate possible differences in fibronectin synthesis in these patients, and to determine the source of increased synovial fluid fibronectin in patients with rheumatoid arthritis.

\section{Patients and methods}

\section{PATIENTS}

Frozen synovial biopsy samples were taken from 22 patients with rheumatoid arthritis (mean age 72 years; 14 women and eight men), 27 with osteoarthritis (mean age 66 years; 16 women and $11 \mathrm{men})$, three with ankylosing spondylitis (mean age 47 years, three men), and three control subjects without inflammatory disease (mean age 66 years, two women and one man). of the extracellular matrix, fibronectin plays studied using immunohistology at light and
TISSUE PREPARATION AND FIXATION

Synovial tissues were freshly collected during operations and immediately snap frozen to preserve mRNA. Tissue blocks were stored at $-70^{\circ} \mathrm{C}$ until sectioning. To prevent RNAse contamination, gloves were worn when handling tissues and slides, and only RNAse free plastic and glassware were used. Wherever possible, solutions were treated overnight with $0 \cdot 1 \% \mathrm{v} / \mathrm{v}$ diethylpyrocarbonate and autoclaved to inhibit RNAses. ${ }^{16}$ All reagents were purchased from Sigma (Poole, United Kingdom) unless otherwise stated.

Tissue sections $(4 \mu \mathrm{m})$ were mounted onto slides coated with $2 \% \mathrm{v} / \mathrm{v}$ aminopropyltriethoxysilane, briefly air dried, and fixed in $4 \%$ 
$\mathbf{w} / \mathbf{v}$ paraformaldehyde in phosphate buffered saline (PBS) (pH 7.3) for 20 minutes at room temperature. After fixation sections were briefly rinsed in distilled water, dehydrated in three changes of absolute alcohol, air dried, and used within two to three hours.

\section{PREPARATION OF RNA PROBES}

A recombinant plasmid $\mathrm{pFH} \mathrm{l}^{17}{ }^{18}$ containing a cDNA insert representing $2 \cdot 1 \mathrm{~kb}$ of human fibronectin mRNA was digested with HindIII and SStI (Boehringer Mannheim, Sussex, United Kingdom). The resultant $2 \mathrm{~kb}$ fragment was separated from the vector by agarose gel electrophoresis. ${ }^{16}$ The required fragment was extracted and purified from the gel using the Isogene method according to the manufacturer's instructions (International Laboratory Services Ltd, London, United Kingdom). The purified fragment was then subcloned into the Riboprobe vector pGEM-blue (Promega Corporation, Madison, USA) to prepare single stranded RNA sense and antisense probes. ${ }^{19} 20$ Linear DNA transcription templates were prepared by restriction with HindIII or SStI. The SStI linearised template was treated with Klenow DNA polymerase (Boehringer Mannheim) to remove 3 ' overhangs, which can lead to aberrant transcripts. ${ }^{1620}$ Radiolabelled RNA probes (specific activity $2.5 \times 10^{8}-3 \times 10^{8} \mathrm{cpm} / \mu \mathrm{g}$ RNA) were prepared by in vitro transcription using CTP labelled with sulphur-35 $\left(2 \cdot 96 \times 10^{10} \mathrm{MBq} /\right.$ mol(Amersham International, United Kingdom) and SP6/T7 RNA polymerase as appropriate (Boehringer Mannheim transcription kit). To achieve optimum probe lengths for tissue penetration, alkaline hydrolysis was carried out to give an average probe length of 100 bases. ${ }^{19}$ The probes were checked by gel electrophoresis and subsequent autoradiography of blots to ensure the correct size of transcripts and the success of hydrolysis. ${ }^{16}$ Radiolabelled probes were stored at $-20^{\circ} \mathrm{C}$ and used within two weeks.

\section{OLIGONUCLEOTIDE POLY $d(T)$ PROBE}

A synthetic poly $d(T)$ probe, 30 nucleotides in length (synthesised on an Applied Biosystems 380A oligonucleotide DNA synthesiser), was used to assess the relative preservation of total mRNA. ${ }^{21}$ Oligonucleotides were fully deprotected after synthesis and used without further purification. To enable the evaluation of any differences in mRNA preservation a less sensitive non-isotopic method of detection was used. The probe was labelled with Digoxigenin-UTP (Boehringer Mannheim) using terminal deoxynucleotide transferase ${ }^{\angle L}$ and was stored at $-20^{\circ} \mathrm{C}$ until use.

\section{TISSUE SECTION PRETREATMENTS}

Sections were rehydrated in PBS before permeabilisation with $0.3 \% \mathrm{w} / \mathrm{v}$ Triton $\mathrm{X}-100$ in PBS for 15 minutes. After washing in PBS the sections were digested with proteinase $\mathrm{K}$ (Sigma) for 20 minutes at $37^{\circ} \mathrm{C}(1 \mu \mathrm{g} / \mathrm{ml}$ in $0.1 \mathrm{M}$ TRIS, $50 \mathrm{mM}$ EDTA, pH 8). Proteinase $\mathrm{K}$ was inhibited by immersion of the sections in $0.1 \mathrm{M}$ glycine/ PBS for five minutes. After fixation for three minutes in $4 \%$ paraformaldehyde/PBS, sections were washed and acetylated in $0.1 \mathrm{M}$ triethanolamine $\mathrm{pH} 8$, and $0.25 \% \mathrm{v} / \mathrm{v}$ acetic anhydride for 10 minutes to reduce the autoradiography background (this step was omitted for the poly $d(T)$ controls). Sections were then dehydrated and air dried before hybridisation.

\section{IN SITU HYBRIDISATION}

Hybridisation was carried out in hybridisation medium consisting of $50 \% \mathrm{v} / \mathrm{v}$ formamide, $2 \times$ SSC $(1 \times$ SSC is $0.15 \mathrm{M}$ sodium chloride, $0.015 \mathrm{M}$ sodium citrate, $\mathrm{pH} 7), 10 \% \mathrm{w} / \mathrm{v}$ dextran sulphate, $0.25 \% \mathrm{w} / \mathrm{v}$ bovine serum albumin, $0.25 \%$ w/v Ficoll $400,0.25 \%$ polyvinylpyrrolidone-40, $10 \mathrm{mM}$ TRIS $\mathrm{pH} \mathrm{7.5,}$ $0.5 \% \mathrm{w} / \mathrm{v}$ tetrasodium pyrophosphate, $0.5 \% \mathrm{w} / \mathrm{v}$ sodium dodecyl sulphate, $10 \mathrm{mM}$ dithiothreitol, and $250 \mu \mathrm{g} / \mathrm{ml}$ denatured salmon sperm DNA. Radiolabelled RNA probes were diluted to give a concentration of $0.2 \mathrm{ng} / \mu \mathrm{l}$ of hybridisation medium $\left(5 \times 10^{4}-6 \times 10^{4} \mathrm{cpm} / \mu \mathrm{l}\right)$ and were denatured at $80^{\circ} \mathrm{C}$ for one minute before incubation with the sections. The poly $d(T)$ probe was diluted to give a concentration of $1 \mathrm{ng} / \mu \mathrm{l}$. To achieve even coverage of the hybridisation solution, coverslips were placed over the sections. Hybridisation was carried out at $37^{\circ} \mathrm{C}$ for approximately 16 hours in a humid chamber.

\section{WASHES AFTER HYBRIDISATION}

Coverslips were dislodged by immersion in $4 \times$ SSC. Excess probe was removed by two washes in $4 \times$ SSC followed by a $2 \times$ SSC wash (20 minutes each at $37^{\circ} \mathrm{C}$ ). Unhybridised RNA probe was removed by incubation with $20 \mu \mathrm{g} / \mathrm{ml}$ RNAse A (Sigma, DNAse free) in $0.5 \mathrm{M} \mathrm{NaCl}$; $10 \mathrm{mM}$ TRIS hydrochloride $\mathrm{pH} 8 ; 1 \mathrm{mM}$ EDTA for 30 minutes at $37^{\circ} \mathrm{C}$. Sections were then washed in $2 \times$ SSC and finally in $0.1 \times$ SSC for 30 minutes at $37^{\circ} \mathrm{C}$ before dehydration in graded alcohols containing $0.3 \mathrm{M}$ ammonium acetate (the dehydration step being omitted for the poly $d(T)$ controls).

\section{AUTORADIOGRAPHY}

Dried slides were dipped in $50 \%(\mathrm{v} / \mathrm{v}$ in distilled water) Ilford K5 nuclear emulsion (Ilford, Mobberly, United Kingdom), and air dried for a minimum of two hours before exposure in darkness for four days at $4^{\circ} \mathrm{C}$. Sections were developed in Kodak D19 developer, fixed in Hypam fix (Kodak, Hemel Hempstead, United Kingdom) and were counterstained with haematoxylin.

DETECTION OF POLY $d(T)$ PROBE

After the posthybridisation treatments the sections were washed in TBS $(0.05 \mathrm{M}$ TRIS, $0.15 \mathrm{M} \mathrm{NaCl}, 2 \mathrm{mM} \mathrm{MgCl}_{2}, \mathrm{pH} \mathrm{7.6)}$ and blocked with $3 \%$ normal sheep serum for 20 minutes. Sections were then incubated with alkaline phosphatase conjugated sheep antidigoxigenin (Boehringer Mannheim), diluted $1: 200$ in TBS containing 3\% normal sheep 
serum, for 30 minutes. After washing the sections were transferred to TRIS developing buffer (0.1 M TRIS, $0 \cdot 1 \mathrm{M} \mathrm{NaCl}, 5 \mathrm{mM} \mathrm{MgCl}_{2}$, pH 9.5). Immunohistochemical detection was carried out using NBT/BCIP $(0.3 \mathrm{mg} / \mathrm{ml}$ nitroblue tetrazolium, $0.15 \mathrm{mg} / \mathrm{ml}$, 5-bromo-4chloro-3-indoxyl phosphate in developing buffer, overnight) and sections were briefly counterstained in haematoxylin.

\section{IN SITU HYBRIDISATION CONTROLS}

Various controls were used to ensure specificity of hybridisation signals. These were: $(a)$ Incubation with hybridisation buffer alone; $(b)$ incubation with radiolabelled sense strand for fibronectin; (c) predigestion of the sections with RNAse A $(20 \mu \mathrm{g} / \mathrm{ml})$; (d) higher stringency post-hybridisation washes, with increasing temperature and formamide content (up to $50 \%$ ) and decreasing salt concentrations (factors which act to destabilise hydrogen bonding $)^{16}{ }^{19}$; and $(e)$ increased autoradiographic exposure (up to two weeks).

\section{IMMUNOHISTOCHEMISTRY}

Serial sections were examined by immunohistochemistry to compare the distributions of fibronectin protein with message. Cryostat sections were acetone fixed for 10 minutes at room temperature, air dried, and incubated with polyclonal rabbit antihuman fibronectin (Dako, High Wycombe, United Kingdom) at a dilution of 1:200 in PBS for 45 minutes. Immunohistochemical detection was with fluorescein (FITC) conjugated swine antirabbit at a dilution of 1:20 (Dako). Sections were then glycerol mounted and visualised by fluorescence microscopy.

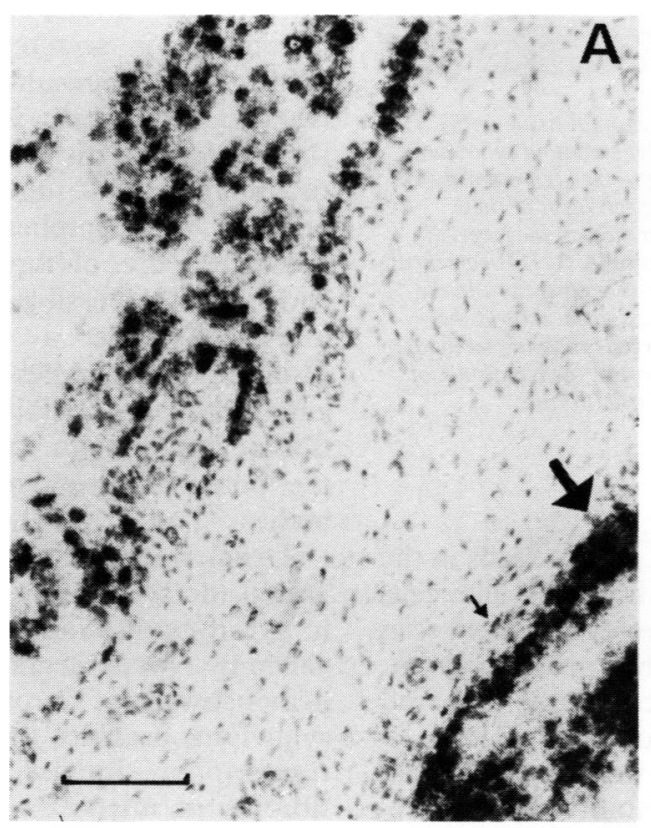

\section{Results}

Sites of hybridisation for fibronectin mRNA were seen as aggregates of silver grains over the cytoplasm of positive cells (fig 1A). No signal above background was obtained with hybridisation buffer alone, or with the radiolabelled sense strand for fibronectin mRNA. Predigestion of the section with RNAse completely abolished the hybridisation signal for the antisense probe (fig 1B). Higher stringency washes, which reduce mismatch base pairing of hybrids, decreased the overall background but did not alter the specific signal. These results confirm that the signal obtained with the antisense probe results from specific hybridisation of the probe with fibronectin mRNA.

Intense hybridisation signals for fibronectin mRNA were localised within the synovial lining cell layer of all biopsy samples studied, and almost all of these cells were positive (fig 1A). Where there was synovial lining cell hyperplasia there was a concomitant increase in the number of cells containing fibronectin mRNA (fig 1A). Owing to the high intensity of the signal in the lining cell layer, it was not usually possible to observe differences in the levels of fibronectin mRNA between cells of the lining layer, although biopsy samples giving lower hybridisation signals did show considerable variations in the level of fibronectin mRNA in adjacent cells of the lining cell layer (fig 2).

Levels of fibronectin mRNA within the synovial lining cells were variable between patients but did not appear to relate to diagnosis or the underlying inflammatory cell infiltrate (fig 2). There were few positive cells in the subintimal layers, and where present these cells gave only low levels of signal (fig 1A). Increasing the duration of autoradiographic exposure gave higher overall signals (including background)

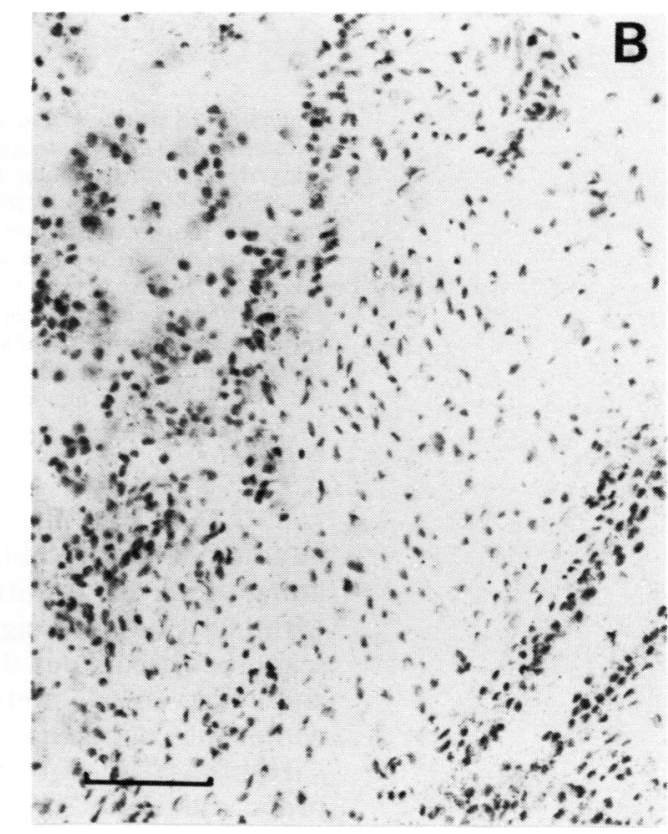

Figure I In situ hybridisation of rheumatoid synovial tissue. (A) Hybridisation with antisense probe for fibronectin. Intense signals are localised in the synovial lining cells, almost all of these cells being positive. Note the increase in the number of positive cells at sites of synovial lining cell hyperplasia (large arrow). Occasional positive cells of fibroblast-like appearance were seen within the subintimal tissue, with a weaker signal (small arrow). (B) Comparable section predigested with RNAse. Hybridisation with the antisense probe is completely abolished. Bar $=100 \mu \mathrm{m}$. 



Figure 2 In situ hybridisation of synovial tissue with antisense probe for fibronectin. (A) Rheumatoid synovium. $(B)$ Osteoarthritic synovium. Owing to the high intensity of the signal for fibronectin in the lining cell layer of these samples it is difficult to observe differences in the levels of fibronectin $m R N A$ between adjacent cells. $(C)$ Osteoarthritic synovium with low signals. Considerable variations in the level of fibronectin mRNA between adjacent cells of the lining cell layer are discernible. Two cells showing moderate labelling are indicated with small arrows, the remainder of the lining cells giving low signals. Bar $=100 \mu \mathrm{m}$.

but did not reveal additional positive cells in the lining cell layer. Additional fibroblast-like cells with lower levels of signal were, however, seen scattered throughout the subintimal synovium, and weak signals were occasionally observed within the endothelial cells of blood vessels.

Hybridisation of sections with the poly $d(T)$ probe did show some variability in the preservation of total mRNA between biopsy samples, but, variations in the levels of fibronectin mRNA did not reflect these differences. Pretreatment of the sections with RNAse completely abolished the signal with the poly $d(T)$ probe, confirming that the technique is identifying an RNA target.

Immunoreactive fibronectin was evident as a dense fibrillar meshwork surrounding the cells of the lining cell layer and was increased at sites of synovial cell hyperplasia. Fibronectin was also prominent in the perivascular connective tissue and basement membranes of small blood vessels. Comparison of the distribution of fibronectin mRNA with that of immunoreactive fibronectin showed a positive relationship between message and protein product at the lining cell layer, but not in the deeper layers. At sites of synovial lining cell hyperplasia there was an increase in the number of cells containing message and the level of extracellular protein surrounding these cells. Occasional cells containing intracellular fibronectin were also evident at this site. In the subintimal tissue, while immunoreactive fibronectin was especially marked around small blood vessels, virtually no hybridisation signal for fibronectin mRNA was seen. The distribution of immunoreactive fibronectin in our study was consistent with that described in previous work. ${ }^{5-12}$

\section{Discussion}

Fibronectin plays an important part in cell-cell and cell-matrix interactions and is capable of influencing the proliferation, differentiation and organisation of cells within a tissue. ${ }^{1-4}$ Owing to its central roles in inflammation, tissue development, and remodelling, various studies have investigated the distribution of fibronectin in inflammatory joint tissue. ${ }^{5-12}$ The site of fibronectin synthesis within the synovium has been the subject of debate as different molecular forms of the protein show immunological cross reactivity. Intracellular fibronectin has been shown in synovial lining cells by immunohistochemistry at light and electron microscopic levels, 56910 and extracellular fibronectin is secreted by synovial cells in culture. ${ }^{14}$ These results suggest that fibronectin is synthesised locally within the synovium and that the lining cells provide a source of synovial tissue and fluid fibronectin. Other studies, however, have implicated endothelial cells as the major source of fibronectin in the synovium, and it is also possible that plasma fibronectin may contribute a significant proportion. Monoclonal antibodies have been used to differentiate between cellular and plasma forms of fibronectin, though there are questions about the potential cross reactivities of these antibodies. ${ }^{2324}$

To determine the sites of fibronectin synthesis within the synovium we used the technique of in situ hybridisation. As mRNA molecules are generally rapidly degraded within cells, ${ }^{16} 19$ the demonstration of fibronectin mRNA within the synovium provides evidence of active gene transcription. Intense hybridisation signals for fibronectin mRNA were localised within the synovial lining layer of all biopsy samples studied and almost all of these cells were positive. This was consistent with the distribution of extracellular protein at this site. Owing to the high intensity and poor cellular 
resolution of the signal it was not possible to quantify the proportion of positive and negative lining cells. There were few positive cells in the subintimal layers, and where present these cells gave comparatively low signals. Little fibronectin mRNA was localised to the endothelial cells of blood vessels, though abundant immunoreactive fibronectin was present in the perivascular connective tissue and basement membranes at this site. In cells of macrophage and fibroblast lineage the control of fibronectin synthesis has been shown to be mainly at the level of transcription ${ }^{15} 25-27$ which is therefore likely to be so for synovial lining cells, as these are thought to be of the same lineages. ${ }^{12}$ Thus our results signify that the cells of the synovial lining are the major site of active fibronectin synthesis, and presumably secretion, in the synovium.

Increasing the duration of autoradiographic exposure showed additional positive endothelial and fibroblast-like cells within the subintimal tissue, demonstrating the lower comparative expression of fibronectin by these cells. Different levels of gene expression shown by cells of the lining layer and underlying tissue could be a reflection of different turnover rates of the protein, or the synthesis of different molecular forms of the molecule. For example, basement membrane fibronectin produced by endothelial cells may be relatively long lived and therefore these cells would have a slower turnover of the protein. Fibronectin produced by synovial lining cells may be of a form which is more susceptible to degradation by proteases, giving a higher turnover of the protein at this site. Synovial fluid analysis has shown that degraded fibronectin is often found. ${ }^{13} 28$ The presence of degraded fibronectin in synovial fluid could indicate that synovial lining cell fibronectin is more susceptible to enzymic degradation, though there is no direct evidence that this is true. In rheumatoid arthritis, but not other arthritides, fragmented fibronectin is associated with immune complexes. ${ }^{28}$ The incorporation of fragmented fibronectin into immune complexes may impair their effective removal from the joint, thereby leading to tissue damage via complement activation. Again, it is not clear whether the different degradation products of fibronectin in rheumatoid arthritis are related to the synthesis of a different molecular form of the protein, or are due to differences in the local environment.

Immunohistochemical studies at the electron microscope level have indicated that fibronectin is synthesised predominantly by fibroblast-like type B cells of the lining layer. ${ }^{10}$ Our results suggest that fibronectin is synthesised by macrophage-like type A and type B cells. Owing to the high intensity of silver grains over the lining cells in most biopsy samples, relative differences in gene expression between the lining cells were not discernible. Considerable variations, however, were evident in biopsy samples which gave lower overall signals. Variations in gene expression across the lining layer may be due to different levels of expression in type $A$ and type $B$ cells. It has been shown that cells of similar lineage, present in the same anatomical compartment, can vary considerably in the expression of the fibronectin gene, indicating that not only tissue specific controls are involved in the expression of fibronectin but additional controls at the cellular level are implicated. ${ }^{15}$ Therefore, variations in expression across the lining cell layer may also be shown by cells of the same lineage.

The overall levels of fibronectin gene expression localised within the cells of the synovial lining cell layer were variable between patients. These variations did not appear to relate to the diagnosis or to the degree of underlying inflammatory cell infiltrate. Differences were not due to the relative preservation of total mRNA, which was assessed by hybridisation of serial sections with a poly $\mathrm{d}(\mathrm{T})$ probe. Comparison of different regions of the synovial lining in individual patients using frozen tissue is difficult. Only relatively small areas of tissue can be sectioned, and morphology and localisation with respect to the rest of the joint is poor. Variations in the hybridisation signal between patients may simply reflect differences in the levels of fibronectin synthesis in different areas of the synovium. To investigate this question we are currently adapting our method for application to formalin fixed, paraffin embedded tissues, allowing larger areas of tissue to be examined.

In areas of synovial lining cell hyperplasia, there was a concomitant increase in the number of cells containing fibronectin mRNA, with an associated increase in the deposition of immunoreactive fibronectin at this site. These results suggest that the overall increase in fibronectin production in the hyperplastic synovium is not due to increased levels of synthesis by individual lining cells, but that it is mediated by an increase in number of cells actively synthesising fibronectin. This increase in fibronectin synthesis is likely to be a major cause of increased synovial fluid fibronectin levels in inflammatory joint disease. Although the distribution of fibronectin mRNA and immunoreactive fibronectin is not disease specific, there is considerable evidence that fibronectin may influence the chronicity of inflammatory joint disease by providing an appropriate environment to support connective tissue proliferation and recruitment of cells to the synovium. ${ }^{11} 12$

In conclusion, we have shown the synthesis of fibronectin within cells of the synovial lining layer. These cells synthesise far higher levels of fibronectin message than subintimal endothelial and fibroblast-like cells, indicating that they are the major source of fibronectin in synovial tissue. To further our understanding of the precise part played by fibronectin in the pathogenesis of inflammatory joint disease it will be important to determine the molecular form(s) of fibronectin synthesised and secreted by synovial lining cells, and to relate these to degradation products in the synovial fluid.

This work was supported by the Joint Research Board of St Bartholomew's Hospital and the Arthritis and Rheumatism Council. We thank Peter Crocker for the photomicrography and Ian Thompson for providing the oligonucleotide used in this study. Dr Scott is the Muir Hambro Research Fellow of the Royal College of Physicians. Dr F E Baralle (William Dunn 
School of Pathology, Oxford University, Oxford, Unite Kingdom) kindly provided the recombinant plasma pFH containing a cDNA insert representing $2 \cdot 1 \mathrm{~kb}$ of huma fibronectin mRNA.

1 Ruoslahti E. Fibronectin and its receptors. Annu Rev Biochem 1988; 57: 375-413.

Yamada $K$ M. Fibronectins: structure, functions and receptors. Curr Opin Cell Biol 1989; 1: 956-63.

3 Hynes R. Molecular biology of fibronectin. Annu Rev Cell Biol 1985; 1: 67-90.

4 Linder E, Stenman S, Lehto V P, Vaheri A. Distribution of fibronectin in human tissues and relationship to other connective tissue components. Ann NYAcad Sci 1978; 312: $151-9$.

5 Scott $\mathrm{D} L$, Wainwright A C, Walton $\mathrm{K} \mathrm{W}$, Williamson $\mathrm{N}$. Significance of fibronectin in rheumatoid arthritis and osteoarthritis. Ann Rheum Dis 1981; 40: 142-53.

6 Scott D L, Delamere J P, Walton K W. The distribution of fibronectin in the pannus in rheumatoid arthritis. $B r \mathcal{F} \operatorname{Exp}$ Pathol 1981; 62: 362-8.

7 Vartio T, Vaheri A, von Essen R, Isomaki H, Stenman S. Fibronectin in synovial fluid and tissue in rheumatoid arthritis. Eur $\mathcal{F}$ Clin Invest 1981; 11: 207-12.

8 Clemmensen I, Holund B, Andersen R B. Fibrin and fibronectin in rheumatoid synovial membrane and rheumafibronectin in rheumatoid synovial membrane and rheuma

9 Mayston V, Mapp P I, Davies P G, Revell P A. Fibronectin in the synovium of chronic inflammatory joint disease. (129-33.

10 Mapp P I, Revell P A. Fibronectin production by synovial intimal cells. Rheumatol Int 1985; 5: 229-37.

11 Scott D L, Walton $\mathrm{K}$ W. The significance of fibronectin in rheumatoid arthritis. Semin Arthritis Rheum 1984; 13: 244-54.

12 Scott D L, Mapp P, Herbert K E. Fibronectin and rheumatic disease. In: Carsons S E, ed. Fibronectin in health and disease. Boca Rato, FL: CRC Press, 1989: 255-68.

13 Clemmensen I Andersen R B. Different molecular forms of fibronectin in rheumatoid synovial fluid. Arthritis Rheum 1982; 25: 25-31.

14 Lavietes B B, Carsons S, Diamond H S, Laskin R S. Synthesis, secretion, and deposition of fibronectin in Synthesis, secretion, and deposition of fibronectin in 1016-26.

15 Adachi K, Yamauchi K, Bernaudin J, Fouret P, Ferrans V J, Crystal R G. Evaluation of fibronectin gene expression by in situ hybridisation. Am F Pathol 1988; 133: 193-203.
16 Sambrook J, Fritsch E F, Maniatis T. Molecular cloning. A laboratory manual. 2nd ed. Cold Spring Harbor: Cold Spring Harbor Laboratory Press, 1989.

17 Kornblihtt A R, Vibe-Pedersen K, Baralle F E. Isolation and characterisation of cDNA clones for human and bovine fibronectins. Proc Natl Acad Sci USA 1983; 80: 3218-22.

18 Kornblihtt A R, Vibe-Pedersen $K$, Baralle $F$ E. Human fibronectin: molecular cloning evidence for two mRNA species differing by an internal segment coding for structral domain. $E M B O \mathcal{f} 1984 ; 3: 221-6$.

19 Angerer L M, Stoler M H, Angerer R C. In situ hybridisation with RNA probes: an annotated recipe. In: Valentino $\mathrm{K} L$, with RNA probes: an annotated recipe. In: Valentino $\mathrm{K} L$, Eberwine $\mathrm{H}$, Barchas $\mathrm{D}$, eds. In situ hybridisationPress, 1987: 42-70.

20 Promega Corporation. Transcription in vitro. In: Promega protocols and applications guide. Madison: Promega Corporation, 1991: 33-48.

21 Pringle J H, Primrose L, Kind C N, Talbot I C, Lauder I. In situ hybridisation demonstration of poly-adenylated RNA sequences in formalin-fixed paraffin sections using biotinylated oligonucleotide poly $\mathrm{d}(\mathrm{T})$ probe. $\mathcal{F}$ Patho 1989; 158: 279-86.

22 Schmitz G G, Walter T, Seibl R, Kessler C. Nonradioactive lahelling of oligonucleotides in vitro with the hapten digoxigenin by tailing with terminal transferase. Anal Biochem 1991; 192: 222-31.

23 Atherton B T, Hynes R O. A difference between plasma and cellular fibronectins located with monoclonal antibodies. cellular fibronectins

24 Walle T K Vartio T, Helve T, Virtanen I, Kurki P Cellular fibronectin in rheumatoid synovium and synovial fluid: a possible factor contributing to lymphocytic infiltration. Scand F Immunol 1990; 31: $535-40$.

25 Yamauchi K, Martinet Y, Crystal R G. Modulation of fibronectin gene expression in human mononuclear phagocytes. F Clin Invest 1987; 80: 1720-7.

26 Raghow R, Lurie S, Seyer J M, Kang A H. Profiles of steady state levels of messenger RNAs coding for type I procollagen, elastin, and fibronectin in hamster lungs undergoing bleomycin-induced interstitial pulmonary fibrosis. 7 Clin Invest 1985; 76: 1733-9.

27 Tyagi J S, Hirano H, Merlino G T, Pastan I. Transcriptional control of the fibronectin gene in chick embryo fibroblasts transformed by Rous sarcoma virus. 7 Biol Chem 1983; 258: $5787-93$.

28 Griffiths A M, Herbert $K$ E, Perret D, Scott D L. Fragmented fibronectin and other synovial fluid proteins in Fragmented fibronectin and other synovial fluid proteins in chronic arthritis: their relation
Chim Acta 1989; 184: 133-46. 